\title{
Hypertensive Disorders: Prevalence, Perinatal Outcomes and Cesarean Section Rates in Pregnant Women Hospitalized for Delivery
}

\section{Distúrbios hipertensivos: Prevalência, resultados perinatais $e$ taxas de cesarianas em gestantes hospitalizadas para o parto}

Francisco Lírio Ramos Filho ${ }^{10}$ Carlos Maurício de Figueiredo Antunes ${ }^{10}$

${ }^{1}$ Santa Casa de Belo Horizonte, Belo Horizonte, MG, Brazil

Address for correspondence Francisco Lírio Ramos Filho,

Rev Bras Ginecol Obstet 2020;42(11):690-696.

\begin{abstract}
Maternidade Hilda Brandão, Santa Casa de Belo Horizonte, Avenida Francisco Sales 1.111, Belo Horizonte, MG, 30150-221, Brazil
\end{abstract} (e-mail: franciscolirioramos@gmail.com).

\begin{abstract}
Keywords

- pre-eclampsia

- prevalence

- cesarean section

- preterm infant

- low birthweight infant
\end{abstract}

Resumo
Objective To evaluate the prevalence of hypertensive disorders, perinatal outcomes (preterm infants, low birthweight infants and Apgar score $<7$ at the 5 th minute and fetal deaths) and the cesarean rates in pregnant women hospitalized for delivery at the Maternidade Hilda Brandão da Santa Casa de Belo Horizonte, Belo Horizonte, state of Minas Gerais, Brazil, from March 1, 2008 to February 28, 2018.

Methods A case-control study was performed, and the groups selected for comparison were those of pregnant women with and without hypertensive disorders. Out of the 36,724 women, 4,464 were diagnosed with hypertensive disorders and 32,260 did not present hypertensive disorders

Results The prevalence of hypertensive disorders was $12.16 \%$; the perinatal outcomes and cesarean rates between the 2 groups with and without hypertensive disorders were: preterm infants $(21.70 \%$ versus $9.66 \%$, odds ratio [OR] $2.59,95 \%$ confidence interval $[\mathrm{Cl}], 2.40-2.80, p<0.001)$; low birthweight infants $(24.48 \%$ versus 10.56\%; OR 2.75; 95\% Cl, 2.55-2.96; $p<0.001)$; Apgar score $<7$ at the $5^{\text {th }}$ minute (1.40\% versus $1.10 \%$; OR $1.27 ; 95 \% \mathrm{Cl}, 0.97-1.67 ; p=0.84)$; dead fetuses diagnosed prior to delivery ( $1.90 \%$ versus $0.91 \%$; OR $2.12 ; 95 \% \mathrm{Cl}, 1.67-2.70 ; p<0.001)$; cesarean rates (60.22\% versus $31.21 \%$; OR 3.34; $95 \% \mathrm{Cl}, 3.14-3.55 ; p<0.001)$.

Conclusion Hypertensive disorders are associated with higher rates of cesarean deliveries and higher risk of preterm infants, low birthweight infants and a higher risk of fetal deaths.

Objetivo Avaliar a prevalência dos distúrbios hipertensivos, resultados perinatais (recém-nascidos pré-termo, recém-nascidos de baixo peso, índice de Apgar $<7$ no $5^{\circ}$ minuto e óbitos fetais) e as taxas de cesarianas nas gestantes internadas para assistência ao parto na Maternidade Hilda Brandão da Santa Casa de Belo Horizonte, Belo Horizonte, MG, Brasil, no período de $1^{\circ}$ de março de 2008 a 28 de fevereiro de 2018. received

February 8, 2020

accepted

June 4, 2020
DOI https://doi.org/

$10.1055 / \mathrm{s}-0040-1714134$ ISSN $0100-7203$.
Copyright $\odot 2020$ by Thieme Revinter

Publicações Ltda, Rio de Janeiro, Brazil
License terms

(c) 1 


\section{Palavras-chave \\ - pré-eclâmpsia \\ - prevalência \\ - cesárea \\ - recém-nascido pré-termo \\ - recém-nascido de baixo peso}

\begin{abstract}
Métodos Foi realizado um estudo analítico, observacional, longitudinal. Os grupos selecionados para comparação foram gestantes com e sem distúrbios hipertensivos. Do total de 36.724 gestantes, 4.464 foram diagnosticadas com distúrbios hipertensivos e 32.260 não apresentavam distúrbios hipertensivos.

Resultados A prevalência dos distúrbios hipertensivos foi de 12,16\%; Os resultados perinatais e as taxas de cesarianas entre os 2 grupos de gestantes com e sem distúrbios hipertensivos foram: recém-nascidos pré-termo $(21,70 \%$ versus $9,66 \%$; odds ratio [OR] 2,59; intervalo de confiança [IC] 95\%, 2,40-2,80; $p<0,001)$; recém-nascidos de baixo peso (24,48\% versus 10,56\%; OR 2,75; IC 95\%, 2,55-2,96; $p<0,001)$; índice de Apgar $<7$ no $5^{\circ}$ minuto $(1,40 \%$ versus $1,10 \%$; OR 1,27 ; IC $95 \%, 0,97-1,67$; $p=0,084)$; fetos mortos diagnosticados previamente ao parto $(1,90 \%$ versus $0,91 \%$; OR 2,12; IC 95\%, 1,67-2,70; $p<0,001)$; taxas de cesarianas (60,22\% versus $31,21 \%$; OR 3,34; IC 95\%, 3,14-3,55; $p<0,001)$.

Conclusão Os distúrbios hipertensivos estão associados a maiores taxas de cesarianas, ao maior risco de recém-nascidos pré-termo, recém-nascidos de baixo peso e a um maior risco de óbitos fetais.
\end{abstract}

\section{Introduction}

Hypertensive disorders complicate up to $10 \%$ of all pregnancies and are one of the main causes of maternal and perinatal morbidity and mortality, besides playing a key role in prematurity. ${ }^{1-3}$ Hypertensive disorders are classified into four categories: 1) pre-eclampsia (PE)-eclampsia, 2) chronic hypertension (of any etiology), 3) chronic hypertension with superimposed PE and 4) gestational hypertension. ${ }^{1,4-6}$ Pre-eclampsia affects 2 to $8 \%$ of pregnant women. ${ }^{6}$ The main maternal complications in PE are eclampsia, coagulopathy (disseminated intravascular coagulation), stroke, pulmonary edema, severe renal failure, liver infarction or hemorrhage, myocardial infarction, retinal injury, placental abruption and death. ${ }^{1,5-8}$ Eclampsia affects $\sim 3.2 \%$ of patients suffering from PE with severe features. ${ }^{6,9}$ It occurs in a ratio of $1 / 2000$ deliveries in developed countries and from $1 / 100$ to $1 / 1,700$ deliveries in developing countries. ${ }^{9}$ HELLP syndrome ( $\mathrm{H}$ : hemolysis; EL: elevated liver enzymes; LP: low platelet) is associated with high rates of maternal morbidity and mortality. ${ }^{1,6,10,11}$ Its occurrence is $\sim 1$ to $2 \%$ in patients with PE with severe features. ${ }^{12}$ In PE, placental ischemia may lead to fetal growth restriction and placental abruption with a subsequent increased risk of prematurity. Other complications are perinatal death and hypoxia-related neurological injuries. ${ }^{1,6,13,14}$ Induction of labor can be performed as long as fetal well-being is assured and maternal clinical conditions allow. ${ }^{15,16}$ In cases of gestational hypertension and PE without severe features, pregnancy should be followed-up with maternal and fetal assessment, and delivery can be scheduled for the $37^{\text {th }}$ week of pregnancy. ${ }^{17,18}$ Immediate termination of pregnancy, once diagnosed after 36 weeks, is related to a reduction in the risk of PE with severe features, HELLP syndrome, eclampsia, pulmonary edema and placental abruption, when compared with pregnant women with pregnancy management beyond 36 weeks, neither leading to increased neonatal morbidity nor higher c-section rates. ${ }^{18}$ Gestational hypertension may progress, in almost half of the cases, to PE. ${ }^{1,4,6}$ In cases of gestational hypertension or PE with severe features, delivery is recommended when the diagnosis is done at or beyond the $34^{\text {th }}$ week. ${ }^{19}$ Chronic hypertension $(\mathrm{CH})$ affects up to $5 \%$ of pregnant women. ${ }^{1}$ Maternal risks related to $\mathrm{CH}$ such as maternal mortality, stroke, pulmonary edema or renal failure are 5 to 6 times higher than in normotensive women. ${ }^{20,21}$ The risk of gestational diabetes is also increased. ${ }^{22}$ Increased prematurity is directly related to the indication for termination of pregnancy, with a 2-fold higher incidence of fetal growth restriction when compared with women not affected by $\mathrm{CH}^{23}$ Chronic hypertension with superimposed $\mathrm{PE}$ is characterized by the onset of $\mathrm{PE}$ in hypertensive patients prior to pregnancy. It affects from 20 to $50 \%$ of chronically hypertensive patients. ${ }^{20,24,25}$

\section{Cesarean Section Rates}

The number of cesarean sections has been increasing over the years around the world. Global rates increased from $12.1 \%$ in 2000 to $21.1 \%$ in $2015 .{ }^{26}$ In Brazil, in 2010, c-section rates reached as high as $52.33 \%$ of all deliveries and $55.43 \%$, in $2016 .^{27}$ The mode of delivery in patients with hypertensive disorders will depend on maternal and fetal clinical conditions as well as on gestational age. ${ }^{6}$

\section{Preterm Infant}

Prematurity is the main cause of neonatal morbidity and mortality. Preterm infants are those born between the $20^{\text {th }}$ and before the full 37 weeks of gestation, in other words, 36 weeks and 6 days. ${ }^{28}$ Considering 2010 worldwide figures, $15,000,000$ out of $135,000,000$ newborns were preterm, accounting for $11.1 \%$ of all births. ${ }^{29}$ In Brazil, preterm birth rates in 2016 reached up to $11.34 \% .{ }^{27}$ 
Hypertensive Disorders: Prevalence, Perinatal Outcomes and Cesarean Section Rates in Pregnant Ramos Filho,

\section{Low Birthweight Infant}

Newborns $<2,500 \mathrm{~g}$ are already considered low weight. ${ }^{28}$ About 20 million low birthweight and premature newborns are born annually around the world, and one third die before reaching the age of 1 year. ${ }^{30}$ In Brazil, perinatal conditions such as birth asphyxia, infections and respiratory problems are the main causes of infant mortality and are more frequent in preterm and low birthweight infants. ${ }^{30}$

\section{APGAR Score}

The APGAR score was described by Dr. Virginia Apgar in 1953 and is a tool for classifying the clinical condition of newborns soon after birth and assessing the effectiveness of resuscitation measures whenever necessary. ${ }^{31}$ The persistence of a low APGAR score at the $5^{\text {th }}$ minute indicates the need for further therapeutic efforts and the severity of the underlying problem of the baby. If the 5-minute APGAR score is $>6$, perinatal asphyxia is rather unlikely to happen. ${ }^{32,33}$ The present study aimed to evaluate the prevalence of hypertensive disorders, perinatal outcomes and the cesarean rates in pregnant women hospitalized for delivery at the Maternidade Hilda Brandão da Santa Casa de Belo Horizonte, Belo Horizonte, state of Minas Gerais, Brazil.

\section{Methods}

\section{Study Design and Participants}

An analytical, observational, retrospective, longitudinal, casecontrol study was performed. The groups selected to be compared were pregnant women with and without hypertensive disorders admitted to the hospital for delivery from March 1st, 2008 to February 28, 2018 at the Maternidade Hilda Brandão da Santa Casa de Belo Horizonte, state of Minas Gerais, Brazil. Out of the 43,775 admissions performed, 36,724 were pregnant women admitted for delivery. A total of 32,260 of all women admitted for childbirth had no hypertensive disorders, and 4,464 were diagnosed with hypertensive disorders. In the 10-year period of the study (March 1, 2008 to February 28, 2018), 740 pregnancies were multifetal gestations, with an incidence of $2.02 \%$ in the general population, of $1.95 \%$ in pregnant women without hypertensive disorders and of $2.49 \%$ in pregnant women with hypertensive disorders. Due to multifetal gestations, the 36,724 pregnant women admitted for delivery gave birth to 37,464 newborns. The 32,260 pregnant women without hypertensive disorders hospitalized for delivery care gave birth to 32,889 newborns. The 4,464 pregnant women with hypertensive disorders hospitalized for delivery care gave birth to 4,575 newborns.

\section{Outcomes Measures}

The primary outcome was the prevalence of hypertensive disorders and the secondary outcomes were c-section rates and perinatal outcomes (APGAR score $<7$ at 5 minutes, low birthweight (LBW) infants, preterm infants and stillbirths) in pregnant women admitted to the hospital with and without hypertensive disorders for delivery care.

\section{Inclusion and Exclusion Criteria}

All patients admitted for delivery care (36,724 patients) were included in the present study. Patients admitted for other procedures (clinical treatment, uterine curettage, laparotomies, cerclages and other procedures) were excluded from the study.

\section{Ethical Protocol}

Informed consent was waived by the Research Ethics Committee of the Santa Casa de Belo Horizonte given the fact that the analysis of the statistical database was performed after the patients were discharged from the hospital, with no nominal identification. The present study was approved by the Research Ethics Committee of the Santa Casa de Belo Horizonte (under the number CAAE: 85213418.3.0000.5138).

\section{Statistical Analysis}

The statistical methodology used was the two proportions Ztest for comparisons, with a $5 \%$ significance level. Therefore, $p$-values $<0.05$ were considered statistically significant.

\section{Results}

A total of 36,724 pregnant women were admitted for delivery at the Maternidade Hilda Brandão da Santa Casa de Belo Horizonte, between March 1st, 2008 and February 28, 2018. A total of 32,260 of those had no hypertensive disorders, and 4,464 were diagnosed with hypertensive disorders. The rates of preterm infants, low birthweight infants, APGAR $<7$ at 5 minutes and stillbirths (identified prior to delivery) in the general population were $11.13 \%, 12.25 \%, 1.14 \%$ and $1.03 \%$ respectively. A total of 12,775 c-sections were performed out of the 36,724 deliveries, corresponding to $34.73 \%$ of all cases. The prevalence of hypertensive disorders in patients admitted for delivery was $12.16 \%$, with $8.16 \%$ in the $1^{\text {st }}$ year and $16.91 \%$ in the $10^{\text {th }}$ year (-Fig. 1 ).

The increased prevalence over the years was a consequence of the higher number of high-risk pregnancy patients referred to the Maternidade Hilda Brandão (-Fig. 2).

Considering all 4,464 pregnant women (diagnosed with hypertensive disorders), 2,171 (48.63\%) were classified as PE-eclampsia; 1,057 (23.68\%) were classified as $\mathrm{CH} ; 876$ (19.62\%) were classified as gestational hypertension, and $360(8.06 \%)$ were classified as $\mathrm{CH}$ with superimposed $\mathrm{PE}$ (-Fig. 3).

Throughout the study period, there were 2,531 cases of PE (2,171 women classified as PE-eclampsia and 360 women classified as $\mathrm{CH}$ with superimposed $\mathrm{PE}$ ), with a prevalence of $6.89 \%$, and 876 cases of gestational hypertension, with a prevalence of $2.39 \%$. There were 36 cases of eclampsia, 1 case for every 1,020.1 deliveries, or 1 case for every 70.3 women with PE, with an incidence of $1.42 \%$. There were 115 cases of HELLP syndrome, 105 cases in patients classified as $\mathrm{PE} /$ eclampsia and 10 cases in patients classified as $\mathrm{CH}$ with superimposing $\mathrm{PE}$, with an incidence of $4.54 \%$. There were 1,417 cases of $\mathrm{CH}(1,057$ women classified as $\mathrm{CH}$ and 360 classified as $\mathrm{CH}$ with superimposed $\mathrm{PE}$ ), with a prevalence of 


\section{Hypertensive Disorders - Prevalence}

$18.00 \%$

$16.81 \% 16.91 \%$

$16.00 \%$

$14.00 \%$

$12.00 \%$

$10.00 \%$

$8.00 \%$

$6.00 \%$

$4.00 \%$

$2.00 \%$

$0.00 \%$

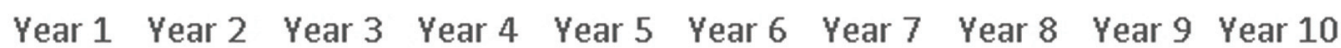

\section{Hypertensive disorders - Prevalence}

Fig. 1 Year on year prevalence of hypertensive disorders at the Maternidade Hilda Brandão.

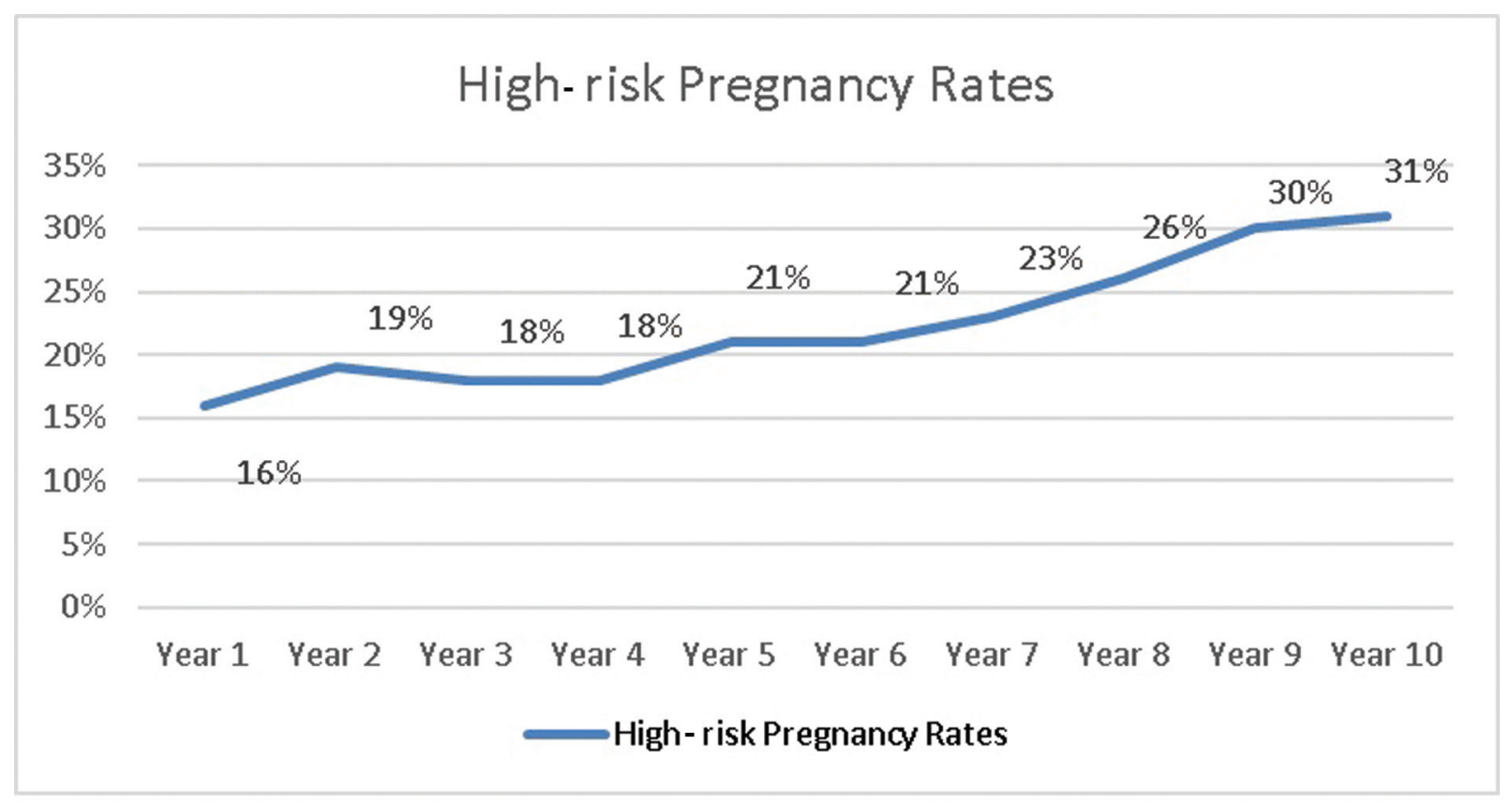

Fig. 2 Year on year prevalence of high-risk pregnancies at the Maternidade Hilda Brandão.

$3.86 \%$. Of the 1,417 pregnant women with $\mathrm{CH}, 360$ had superimposed PE, affecting $25.41 \%$ of women with $\mathrm{CH}$. Cesarean section rates in pregnant women with hypertensive disorders were $60.22 \%$, and in the control group $31.21 \%$; OR 3.34; 95\% CI, 3.14-3.55; $p<0.001$ (-Table 1).

The rate of preterm infant in pregnant women with hypertensive disorders was $21.7 \%$, and in the control group, 9.66\%; OR 2.59; 95\% CI, 2.40-2.80; $p<0.001$ (- Table 2).

The rate of low birthweight (LBW) infants in pregnant women with hypertensive disorders was $24.48 \%$, and in the control group it was 10.56\%; OR 2.75; 95\% CI, 2.55-2.96; $p<0.001$ ( - Table 3).

The rate of infants with APGAR $<7$ at the 5th minute in pregnant women with hypertensive disorders was $1.40 \%$ and $1.10 \%$ in the control group; OR $1.27,95 \% \mathrm{CI}, 0.97-1.67$; $p<0.001$ ( - Table 4).

The dead fetuses diagnosed prior to delivery were excluded from the APGAR analysis (385 in the general population, or $1.03 \%$ ), with $87(1.90 \%)$ out of the total number of newborns in pregnant women with hypertension and 298 
Hypertensive Disorders: Prevalence, Perinatal Outcomes and Cesarean Section Rates in Pregnant Ramos Filho,

\section{Classification of Hypertensive Disorders}

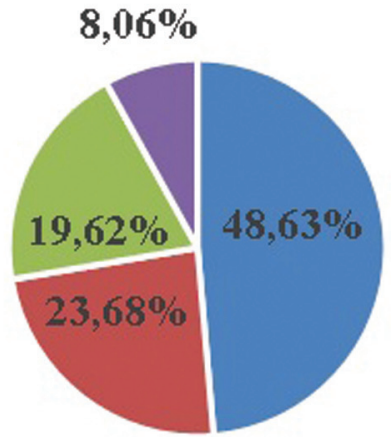

\section{- Pre-eclampsia/Eclampsia \\ - Chronic Hypertension \\ - Gestational Hypertension \\ - Pre-eclampsia Superimposed}

Fig. 3 Classification of hypertensive disorders at the Maternidade Hilda Brandão.

Table 1 Cesarean section rates at the Maternidade Hilda Brandão

\begin{tabular}{|c|c|c|c|c|c|c|c|}
\hline & \multicolumn{2}{|c|}{$\begin{array}{l}\text { Pregnant With } \\
\text { Hypertension }\end{array}$} & \multicolumn{2}{|c|}{$\begin{array}{l}\text { Pregnant Without } \\
\text { Hypertension }\end{array}$} & \multirow[t]{2}{*}{$p$-value ${ }^{*}$} & \multirow[t]{2}{*}{ OR } & \multirow[t]{2}{*}{$95 \% \mathrm{Cl}$} \\
\hline & $\bar{n}$ & (\%) & $n$ & (\%) & & & \\
\hline C Sections & 2,688 & $(60.22)$ & 10,068 & $(31.21)$ & $<0.001$ & 3.34 & $3.14-3.55$ \\
\hline Total deliveries & 4,464 & & 32,260 & & & & \\
\hline
\end{tabular}

Abbreviations: $\mathrm{Cl}$, confidence interval; OR, odds ratio.

*Proportion Comparison Z Test.

Table 2 Preterm infant rates at the Maternidade Hilda Brandão

\begin{tabular}{|c|c|c|c|c|c|c|c|}
\hline & \multicolumn{2}{|c|}{$\begin{array}{l}\text { Pregnant With } \\
\text { Hypertension }\end{array}$} & \multicolumn{2}{|c|}{$\begin{array}{l}\text { Pregnant Without } \\
\text { Hypertension }\end{array}$} & \multirow[t]{2}{*}{ p-value* } & \multirow[t]{2}{*}{ OR } & \multirow[t]{2}{*}{$95 \% \mathrm{Cl}$} \\
\hline & $\mathbf{n}$ & $(\%)$ & $\mathbf{n}$ & $(\%)$ & & & \\
\hline Preterm Infant & 993 & $(21.70)$ & 3,178 & $(9.66)$ & $<0.001$ & 2.59 & $2.40-2.80$ \\
\hline Total Infants & 4,575 & & 32,889 & & & & \\
\hline
\end{tabular}

Abbreviations: $\mathrm{Cl}$, confidence interval; OR, odds ratio.

*Proportion Comparison Z Test.

Table 3 Low birthweight infant rates at the Maternidade Hilda Brandão

\begin{tabular}{|c|c|c|c|c|c|c|c|}
\hline & \multicolumn{2}{|c|}{$\begin{array}{l}\text { Pregnant With } \\
\text { Hypertension }\end{array}$} & \multicolumn{2}{|c|}{$\begin{array}{l}\text { Pregnant Without Hy- } \\
\text { pertension }\end{array}$} & \multirow[t]{2}{*}{ p-value* } & \multirow[t]{2}{*}{ OR } & \multirow[t]{2}{*}{$95 \% \mathrm{Cl}$} \\
\hline & $n$ & $(\%)$ & $\mathbf{n}$ & (\%) & & & \\
\hline LBW Infant & 1,120 & $(24.48)$ & 3,472 & $(10.56)$ & $<0.001$ & 2.75 & $2.55-2.96$ \\
\hline Total Infants & 4,575 & & 32,889 & & & & \\
\hline
\end{tabular}

Abbreviations: $\mathrm{Cl}$, confidence interval; LBW, low birthweight; OR, odds ratio.

*Proportion Comparison Z Test. 
Table 4 APGAR $<7$ at 5th minute rates at the Maternidade Hilda Brandão

\begin{tabular}{|c|c|c|c|c|c|c|c|}
\hline & \multicolumn{2}{|c|}{$\begin{array}{l}\text { Pregnant With } \\
\text { Hypertension }\end{array}$} & \multicolumn{2}{|c|}{$\begin{array}{l}\text { Pregnant Without } \\
\text { Hypertension }\end{array}$} & \multirow[t]{2}{*}{ p-value* } & \multirow[t]{2}{*}{ OR } & \multirow[t]{2}{*}{$95 \% \mathrm{Cl}$} \\
\hline & $\bar{n}$ & (\%) & $n$ & (\%) & & & \\
\hline APGAR $<7$ & 63 & $(1.40)$ & 360 & $(1.10)$ & 0.084 & 1.27 & $0.97-1.67$ \\
\hline Total Infants & 4,488 & & 32,591 & & & & \\
\hline
\end{tabular}

Abbreviations: $\mathrm{Cl}$, confidence interval; OR, odds ratio.

*Proportion Comparison Z Test.

Table 5 Dead fetuses rates before delivery at the Maternidade Hilda Brandão

\begin{tabular}{|c|c|c|c|c|c|c|c|}
\hline & \multicolumn{2}{|c|}{$\begin{array}{l}\text { Pregnant With } \\
\text { Hypertension }\end{array}$} & \multicolumn{2}{|c|}{$\begin{array}{l}\text { Pregnant Without } \\
\text { Hypertension }\end{array}$} & \multirow[t]{2}{*}{ p-value* } & \multirow[t]{2}{*}{ OR } & \multirow[t]{2}{*}{$95 \% \mathrm{Cl}$} \\
\hline & $\bar{n}$ & (\%) & $n$ & (\%) & & & \\
\hline Dead fetuses & 87 & $(1.90)$ & 298 & $(0.91)$ & $<0.001$ & 2.12 & $1.67-2.70$ \\
\hline Total Infants & 4,575 & & 32,8 & & & & \\
\hline
\end{tabular}

Abbreviations: $\mathrm{Cl}$, confidence interval; $\mathrm{OR}$, odds ratio.

*Proportion Comparison Z Test.

(0.91\%) out of the total number of newborns in pregnant women without hypertension; OR 2.12; 95\% CI, 1.67-2.70; $p<0.001$ (-Table 5).

\section{Discussion}

The Maternidade Hilda Brandão is a reference in high-risk pregnancy in the state of Minas Gerais, Brazil. It was founded on June 24, 1916, being the first maternity hospital in Belo Horizonte. Over the following 10-year period (March 1, 2008 to February 28, 2018), 36,724 deliveries were performed at an average of 306.03 per month. The present study revealed the existence of a statistically significant difference between the proportion of c-sections, preterm infants, LBW infants, and dead fetuses (diagnosed before delivery) for pregnant women with and without hypertensive disorders. It was also shown that there is no significant difference between the proportion of newborns with APGAR score $<7$ at the $5^{\text {th }}$ minute for pregnant women affected or not by hypertensive disorders. Hypertensive disorders complicate up to $10 \%$ of all pregnancies. ${ }^{1}$ In the present study, the prevalence of hypertensive disorders increased from $8.16 \%$ in the $1^{\text {st }}$ year to $16.91 \%$ in the $10^{\text {th }}$ year, with an annual average of $12.16 \%$. High-risk pregnancy (HRP) rates increased from $16 \%$ in the first year of the study to $31 \%$ in the last year, which justifies the increased prevalence of hypertensive disorders. Preeclampsia affects 2 to $8 \%$ of pregnant women and $\mathrm{CH}$ affects up to $5 \%{ }^{1,6}$ In the present study, the prevalence of PE was $6.89 \%$, and $3.86 \%$ for $\mathrm{CH}$. The prevalence of gestational hypertension was $2.39 \%$. Eclampsia affects $\sim 3.2 \%$ of patients with PE with severe features. ${ }^{6,9}$ It occurs in a ratio of $1 / 100$ to $1 / 2,000$ deliveries. ${ }^{9}$ At the Maternidade Hilda Brandão, there were 36 eclampsia cases; 1 per 1,020.1 deliveries; 1 per 70.3 patients with $\mathrm{PE}$, with an incidence of $1.42 \%$. The occurrence of HELLP syndrome is of $\sim 1$ to $2 \%$ in patients with PE with severe features. ${ }^{12}$ At the Maternidade Hilda Brandão, there were 115 HELLP syndrome cases, with an incidence of $4.54 \%$. Chronic hypertension with superimposed PE affects from 20 to $50 \%$ of chronically hypertensive patients. ${ }^{20,24,25}$ In the present study, superimposed PE affected $25.41 \%$ of the patients with $\mathrm{CH}$.

\section{Conclusion}

Hypertensive disorders are associated with a higher proportion of c-section deliveries, preterm newborns and LBW infants. The proportion of dead fetuses before hospital admission for delivery is also higher in pregnant women with hypertensive disorders. Therefore, good prenatal care is essential to prevent fetal death before hospital admission for delivery. The evaluation of newborns by the APGAR score at 5 minutes showed no significant differences between the proportion of newborns with APGAR $<7$ at 5 minutes for pregnant women with and without hypertensive disorders, which leads to the understanding that adequate and timely delivery assistance is critical to good fetal conditions at birth.

\section{Contributions}

Data collection and article writing was performed by the maternity coordinator physician Ramos Filho F. L. Professor Antunes C. M. F. did the analysis and interpretation of data.

Conflict of Interests

The authors have no conflict of interests to declare.

\section{Acknowledgments}

The authors thank the pregnant women of the Maternidade Hilda Brandão da Santa Casa de Belo Horizonte, Belo Horizonte, state of Minas Gerais, Brazil, for enabling the present study. 


\section{References}

1 American College of Obstetricians and Gynecologists; Task Force on Hypertension in Pregnancy. Hypertension in pregnancy. Report of the American College of Obstetricians and Gynecologists' Task Force on Hypertension in Pregnancy. Obstet Gynecol. 2013;122(05): 1122-1131. Doi: 10.1097/01.AOG.0000437382.03963.88

2 Steegers EA, von Dadelszen P, Duvekot JJ, Pijnenborg R. Pre-eclampsia. Lancet. 2010;376(9741):631-644. Doi: 10.1016/S0140-6736 (10)60279-6

3 Khan KS, Wojdyla D, Say L, Gülmezoglu AM, Van Look PF. WHO analysis of causes of maternal death: a systematic review. Lancet. 2006;367(9516):1066-1074. Doi: 10.1016/S0140-6736(06) 68397-9

4 Brown MA, Magee LA, Kenny LC, Karumanchi SA, McCarthy FP, Saito $S$, et al; International Society for the Study of Hypertension in Pregnancy (ISSHP). Hypertensive disorders of pregnancy: ISSHP classification, diagnosis, and management recommendations for international practice. Hypertension. 2018;72(01): 24-43. Doi: 10.1161/HYPERTENSIONAHA.117.10803

5 Malachias MVB, Souza WKSB, Plavnik FL, Machado CA, Malta D, Scala LCN, Fuchs S. 7a Diretriz Brasileira de Hipertensão Arterial. Arq Bras Cardiol. 2016;107(03):1-103

6 ACOG Practice Bulletin No. 202: gestational hypertension and L. Obstet Gynecol. 2019;133(01):e1-e25. Doi: 10.1097/AOG.00000 00000003018

7 Peraçoli JC, Borges VT, Ramos JG, et al. Pré-eclâmpsia/eclâmpsia. São Paulo: Federação Brasileira das Associações de Ginecologia e Obstetrícia (FEBRASGO); 2018

8 Sibai BM. Diagnosis, prevention, and management of eclampsia. Obstet Gynecol. 2005;105(02):402-410. Doi: 10.1097/01.AOG.00 00152351.13671 .99

9 Altman D, Carroli G, Duley L, Farrell B, Moodley J, Neilson J, Smith D, et al; Magpie Trial Collaboration Group. Do women with preeclampsia, and their babies, benefit from magnesium sulphate? The Magpie Trial: a randomised placebo-controlled trial. Lancet. 2002;359(9321):1877-1890. Doi: 10.1016/s0140-6736(02)08778-0

10 Sass N, Korkes HA, Katz L. Síndrome HELLP. São Paulo: Federação Brasileira das Associações de Ginecologia e Obstetrícia (FEBRASGO); 2018

11 Barton JR, Sibai BM. Diagnosis and management of hemolysis, elevated liver enzymes, and low platelets syndrome. Clin Perinatol. 2004;31(04):807-833, vii. Doi: 10.1016/j.clp.2004.06.008

12 Cabral ACV. Guia de bolso de obstetrícia. 2a ed. Rio de Janeiro: Atheneu; 2017

13 Espinoza J, Romero R, Mee Kim Y, Kusanovic JP, Hassan S, Erez O, et al. Normal and abnormal transformation of the spiral arteries during pregnancy. J Perinat Med. 2006;34(06):447-458. Doi: 10.1515/JPM.2006.089

14 Ogge G, Chaiworapongsa T, Romero R, Hussein Y, KusanovicJP, Yeo L, et al. Placental lesions associated with maternal underperfusion are more frequent in early-onset than in late-onset preeclampsia. J Perinat Med. 2011;39(06):641-652. Doi: 10.1515/jpm.2011.098

15 Alexander JM, Bloom SL, McIntire DD, Leveno KJ. Severe preeclampsia and the very low birth weight infant: is induction of labor harmful? Obstet Gynecol. 1999;93(04):485-488. Doi: 10.1016/s0029-7844(98)00488-8

16 Alanis MC, Robinson CJ, Hulsey TC, Ebeling M, Johnson DD. Earlyonset severe preeclampsia: induction of labor vs elective cesarean delivery and neonatal outcomes. Am J Obstet Gynecol. 2008; 199(03):262.e1-262.e6. Doi: 10.1016/j.ajog.2008.06.076

17 Sibai BM. Management of late preterm and early-term pregnancies complicated by mild gestational hypertension/pre-eclampsia. Semin Perinatol. 2011;35(05):292-296. Doi: 10.1053/j. semperi.2011.05.010
18 Koopmans CM, Bijlenga D, Groen H, Mc Vijgen S, Aarnoudse JG, Bekedam DJ, et al; HYPITAT study group. Induction of labour versus expectant monitoring for gestational hypertension or mild pre-eclampsia after 36 weeks' gestation (HYPITAT): a multicentre, open-label randomised controlled trial. Lancet. 2009; 374(9694):979-988. Doi: 10.1016/S0140-6736(09)60736-4

19 Broekhuijsen K, van Baaren GJ, van Pampus MG, Ganzevoort W, Sikkema JM, Woiski MD, et al; HYPITAT-II study group. Immediate delivery versus expectant monitoring for hypertensive disorders of pregnancy between 34 and 37 weeks of gestation (HYPITAT-II): an open-label, randomised controlled trial. Lancet. 2015;385 (9986):2492-2501. Doi: 10.1016/S0140-6736(14)61998-X

20 ACOG Practice Bulletin No. 203: chronic hypertension in pregnancy. Obstet Gynecol. 2019;133(01):e26-e50. Doi: 10.1097/ AOG.0000000000003020

21 Gilbert WM, Young AL, Danielsen B. Pregnancy outcomes in women with chronic hypertension: a population-based study. J Reprod Med. 2007;52(11):1046-1051

22 Zetterström K, Lindeberg SN, Haglund B, Hanson U. Maternal complications in women with chronic hypertension: a population-based cohort study. Acta Obstet Gynecol Scand. 2005;84 (05):419-424. Doi: 10.1111/j.0001-6349.2005.00508.x

23 Panaitescu AM, Syngelaki A, Prodan N, Akolekar R, Nicolaides KH. Chronic hypertension and adverse pregnancy outcome: a cohort study. Ultrasound Obstet Gynecol. 2017;50(02):228-235. Doi: 10.1002/uog. 17493

24 Sibai BM. Chronic hypertension in pregnancy. Obstet Gynecol 2002;100(02):369-377. Doi: 10.1016/s0029-7844(02)02128-2

25 Korkes HA, Sousa FL, Cunha Filho EV, Sass N. Hipertensão arterial crônica e gravidez. São Paulo: Federação Brasileira das Associações de Ginecologia e Obstetrícia (FEBRASGO); 2018

26 Boerma T, Ronsmans C, Melesse DY, Barros AJD, Barros FC, Juan L, et al. Global epidemiology of use of and disparities in caesarean sections. Lancet. 2018;392(10155):1341-1348. Doi: 10.1016/ S0140-6736(18)31928-7

27 Ministério da Saúde. Secretaria de Vigilância em Saúde. Departamento de Análise de Saúde e Vigilância de Doenças não Transmissíveis. Painel de Monitoramento de Nascidos Vivos [Internet]. 2020 [cited 2020 Jan 10]. Available from: http://svs.aids.gov.br/dantps/centrais-de-conteudos/paineis-de-monitoramento/natalidade/nascidos-vivos/

28 Eichenwald EC, Hansen AR, Martin CR, Stark AR. Cloherty and Stark's: manual of neonatal care. 8th ed. Philadelphia: Wolters Kluwer; 2017

29 March of Dimes, The Partnership for Maternal, Newborn \& Child Health, Save the Children, World Health Organization. Born too soon: the global action report on preterm birth. Geneva: World Health Organization; 2012

30 Ministério da Saúde. Secretaria de Atenção à Saúde. Departamento de Ações Programáticas Estratégicas. Atenção humanizada ao recém-nascido de baixo peso: método Canguru: manual técnico [Internet]. Brasília (DF): Editora do Ministério da Saúde; 2013 [cited 2019 Sep 21]. Available from: http://bvsms.saude.gov.br/bvs/publicacoes/atencao_humanizada_recem_nascido_canguru.pdf

31 Apgar V. A proposal for a new method of evaluation of the newborn infant. Curr Res Anest Anal. 1953;32(04):260-267

32 Committee on Obstetric Practice American Academy of Pediatrics - Committee on Fetus and Newborn. Committee Opinion No. 644: The Apgar Score. Obstet Gynecol. 2015;126(04):e52-e55. Doi: 10.1097/AOG.0000000000001104

33 Kasdorf E, Laptook A, Azzopardi D, Jacobs S, Perlman JM. Improving infant outcome with a 10 min Apgar of 0 . Arch Dis Child Fetal Neonatal Ed. 2015;100(02):F102-F105. Doi: 10.1136/archdischild-2014-306687 